\title{
Determining the Spatio-Temporal Dynamics of Land Cover along with Some Socio-Economic Factors in the Olur Planning Unit (Turkey)
}

\author{
Derya MUMCU-KUCUKER ${ }^{1}$, Burak SARI ${ }^{1 *}$ \\ ${ }^{1}$ Karadeniz Technical University, Faculty of Forestry, Forest Engineering Department, 61080, Trabzon
}

\begin{abstract}
Because forest cover changes directly affect the sustainability of the forest value, they should be observed carefully. This study analyzed the spatial and temporal pattern of land use/land cover change (LULCC) along with the effects of some socio-economic factors such as forest crime rates, rural population change, and annual gross national product (GNP) on spatiotemporal change of forest dynamics between 1970 and 2015 in the Olur forest planning unit using ArcGIS software and Patch Analyst extension.The results showed that high forest areas increased by $47.14 \%$ between 1970 and 2015 . Coppice stands completely transitioned to other cover types in 2015 due to the changing of management policy in the case study area. Based on landscape pattern, the total number of patches (NP) increased by $50.07 \%$, and mean patch size (MPS) decreased by $31.88 \%$ during the period. Results indicated that the forest ecosystem became more sensitive as it turned into a more spatially fragmented structure, making continued efforts to maintain biodiversity and insure sustainability a challenge. Depending on the decrease in the rural population and economic growth, there was a serious decrease in forest crime rates. This study has shown that socio-economic factors can be effective on landscape dynamics besides management activities.
\end{abstract}

Keywords: Forest management, land use/land cover change, forest dynamics, landscape metrics, socioeconomic factors.

\section{Olur Planlama Biriminde (Türkiye) Arazi Örtüsünün Bazı Sosyo- Ekonomik Faktörlerle Birlikte Konumsal-Zamansal Dinamiklerinin Belirlenmesi}

\section{Öz}

Orman örtüsünde meydana gelen değişimler orman fonksiyonlarının sürdürülebilirliği üzerinde doğrudan etkili olduğu için dikkatli bir biçimde gözlemlenmelidir. Bu çalışmada, Olur Orman İşletme Şefliği’nde 1970-2015 yılları arasında arazi kullanım/arazi örtüsünde meydana gelen zamansal ve konumsal değişimler; ArcGIS yazılım ve Patch Analizi eklentisi kullanılarak ve orman suç oranları, kırsal nüfus değişimi ve gayri safi milli hasıla değerleri gibi bazı sosyo-ekonomik faktörler dikkate alınarak analiz edilmiştir. Sonuçlar, koru ormanlarında 1970-2015 yılları arasında \%47.14'lük bir artış olduğunu ve uygulanan yönetim politikasındaki değișikliğin etkisiyle baltalık alanların 2015 yılı itibariyle alanda bulunmadığı belirlenmiştir. Patch analizi sonuçlarına göre ise toplam parça sayısı $\% 50.07$ oranında artarken ortalama parça büyüklüğü de $\% 31.88$ oranında azalmıştır. $\mathrm{Bu}$ sonuçlar, orman ekosisteminin konumsal olarak parçalanmış bir yapıya dönüştüğü için daha hassas hale geldiğini ve biyolojik çeşitliliği korumak ve sürdürülebilirliği sağlamak için sürekli çaba sarf edilmesi gerektiğini göstermiştir. Kırsal nüfusun azalmasına ve ekonomik büyümeye bağlı olarak orman suç oranlarında ciddi bir düşüş yaşanmıştır. Bu çalışma amenajman aktivitelerinin yanı sıra sosyo-ekonomik faktörlerin de orman dinamikleri üzerinde etkili olabileceğini göstermiştir.

Anahtar Kelimeler: Orman amenajmanı, arazi kullanım/arazi örtüsü değişimi, orman dinamiği, landscape ölçütleri, sosyo-ekonomik faktörler. 


\section{Introduction}

Forest ecosystems are essential to provide timber production, water supply, wildlife habitat, biodiversity, soil protection, carbon emission, nutrient cycling, and non-wood forest products. Approximately 2.4 billion people benefit from wood to supply basic energy needs. In terms of forested watersheds, $75 \%$ of the world's accessible freshwater needs were supplied (FAO 2015). However, in recent years, natural or human-induced disturbances such as land use/land cover changes (LULCC) and pressures have threatened forest ecosystem productivity and health on the local and global scales through losses of soil and productive lands, diminishing water quality, habitat loss, biodiversity disruption, and climate change (Houghton 1994; Turner et al. 1995; Kilic et al. 2004; Chen et al. 2001; Wang et al. 2006).

LULCC is generally considered to have an important role in ecosystem dynamics (Forman and Godron 1986; Turner 1989; Turner and Gardner 1991; Turner et al. 1991; Naveh and Lieberman 1994; Forman 1995; Cernusca et al. 1999; Olsen et al. 2007; DiBari 2007), referring to a temporal and spatial change in forest functions and structure such as size, shape, composition, and arrangement (Baskent and Jordan 1995). Therefore, a better understanding of spatial and temporal changes in forest ecosystem structure, function, and dynamics is extremely important for the sound decision-making of forest managers for sustainable management of forest ecosystems (Turner et al. 2001).

Spatial and temporal changes in forest ecosystems are strongly affected by the combination of human-induced activities such as illegal tree cutting, overgrazing, and increasing land demand for agriculture (Hietala-Koivu 1999; Mander et al. 1999; Cayuela et al. 2006), the growth rate of population (Wear et al. 1996), socio-economic factors (Zhao et al. 2003), lack of awareness of forest ecological services, expansion of the forests by afforestation or reforestation (Nagashima et al. 2002), and migration from rural areas to urban areas (Doygun and Alphan 2006; Shalaby et al. 2004; Shalaby and Tateishi 2007). However, fewer changes are obtained as a result of natural disturbances such as insects, wildfire, and climate change.

Urbanization is one of the major driving forces to contribute to LULCC and has rapidly increased all over the world (Grimm et al. 2008) As long as the population density around the world increases and the vast majority of the population moves from rural areas to urban areas, the impacts of rapid urbanization will lead to extensive LULCC in particular (Wu et al. 2011).

The socio-economic conditions such as the increase in the human population, urban expansions, economic development, and rise in resource utilization and ecological environment are mainly related to LULCC (Holdgate 1993; Wu et al. 2011). Socio-economic factors such as population dynamics and gross domestic product (GNP) affect forest ecosystems in two ways. On one hand, with rapid urbanization and economic growth, populations migrate from the rural areas to urban areas, and the conflict on land use increases (Xie et al. 2016). To meet the food demand based on the increase in the human population, large amounts of forest lands are converted into agricultural lands. Besides, the expansion of urban areas and economic growth force a large number of agricultural lands to be transformed into residential areas (Wu et al. 2011). On the other hand, with increased economic level, rural areas are used for recreation purposes that affect ecological lands (Xie et al. 2016).

Forest management policies and interventions such as afforestation, forest conservation, and rehabilitation activities have a great potential to affect land use and cover dynamics (Sivrikaya et al. 2007; Bozali et al. 2015). For these purposes, the Forest Rehabilitation Action Plans (GDF, 2006a), the Forest Conversion Action Plan (GDF, 2006b), and National Afforestation and Erosion Control Action Plan (GDF, 2008) led to a significant increase in forested areas.

There has been ecosystem degradation, forest loss, and habitat fragmentation negatively affecting ecosystems all over the world (Laurance 1999; Noss 2001; Armenteras et al. 2003). Habitat fragmentation and forest loss are landscape changes in areas with high human pressure and among the principal causes of biodiversity loss in the world (Chaves and Arango 1998). Fragmentation can have negative effects on biodiversity by increasing the isolation of habitats (Debinski and Holt 2000) and by reducing species richness (Gigord et al. 1999). Deforestation is one of the main reasons for habitat fragmentation, and if the number of patches (NP) increases and patch sizes become very small, it will cause the increase of edge effects and human pressure (Watson et al. 2001; Beier et al. 2002). Empirical studies about rapid human-driven transitions of forest cover figured out that habitat fragmentation can affect flora (Halpen and Spies 1995) and fauna communities (Lomolino and Perault 2000), even causing an increased potential of extinction of species (Loehle and Li 1996) when forest patches are either too small or too degraded (Turner 1996; Renjifo 1999). Spatiotemporal changes on land use or land cover affect communities through modifying interspecific interaction and nutrient flows, changing social relationships, worsening edge 
effects, increasing habitat isolation, and even genetic composition of local populations (Debinski 2000; Watson et al. 2004). As a consequence, it is important to study and document historical dynamics in the structure or composition of forest ecosystems for the understanding of relationships between landscape patterns and ecological processes (Gunlu et al. 2009).

Over the decades, many studies have focused on analyzing spatial and temporal changes of forest ecosystems in terms of different indicators due to the increasing scientific importance of LULCC on global scales (Chen et al. 2001). In this context, some technologies such as remote sensing (RS) and Geographical Information Systems (GIS) and several spatial statistics software such as FRAGSTATS or GIS-linked patch analysis have been used to explain the quantitative evaluation of forest dynamics (Armenteras et al. 2006; Sivrikaya et al. 2007; Akay et al. 2014). Empirical studies about rapid human-driven transitions of forest cover figured out that habitat fragmentation can affect flora (Halpen and Spies 1995) and fauna communities (Lomolino and Perault 2000), even causing an increased potential of extinction of species (Loehle and Li 1996). There are many studies about the impacts of forest conversion and degradation on biodiversity, forest loss and fragmentation, changes in spatial landscape characteristics, and deforestation (Spies et al. 1994; Turner and Corlett 1996; Luque 2000; Imbernon and Branthomme 2001; Steininger et al. 2001; Sader et al. 2001; García-Gigorro and Saura 2005; Kupfer 2006; Echeverria et al. 2006; Gibson et al. 2011).

Most of the previous studies have mainly concentrated on land use dynamics and landscape change patterns by using classified satellite images and GIS (Chen et al. 2001; Gautam et al. 2003; Wakeel et al. 2005; MumcuKucuker et al. 2008; Cakir et al. 2015; Keles et al. 2016, Gol et al. 2018, Zengin and Değermenci 2018, Kaptan and Durkaya 2019). Besides, considerable attention has been given to the analysis of spatiotemporal changes in forest ecosystems through GIS or RS technologies (Keles et al. 2008; Cakir et al. 2008a; Sivrikaya et al. 2011; Mumcu-Kucuker and Baskent 2017, Kaptan, 2021 and Bozali, 2021). Until now, there has been little investigation into the effects of rural population change on spatial and temporal changes of forest structure; however, no study has yet attempted to determine the effects of forest crime rates, rural population change, and annual gross national product (GNP).

The overall objective of this study is to analyze the impacts of forest crime rates, rural population change, and annual GNP on spatial and temporal changes of forest ecosystems in the east part of Turkey over about 45 years. In this context, the investigation focuses primarily on temporal changes in the Olur forest planning unit between 1970 and 2015 based on land use/land cover classes, canopy cover, and development stage. In addition to that, spatial analyses of changes in forest structure were evaluated separately using Patch Analyst tools of Arc/GIS in terms of forest stand cover type maps from forest management plans.

\section{Material and Methods}

\subsection{Study area}

The Olur forest planning unit is located in the Erzurum province of eastern Turkey (Figure 1) and covers a total area of $80,861.51$ ha. About $35.5 \%$ is forested area and consists mainly of the tree species Scots pine (Pinus sylvestris) and Juniper (Juniperus sp.). The altitude ranges from 720 to $2950 \mathrm{~m}$ asl. According to the long-term measurement from 1970 to 2005, the annual mean temperature of the planning unit is $9.8^{\circ} \mathrm{C}$, and the mean annual total precipitation is $393.3 \mathrm{~mm}$ (TSMS, 2016). Modern farming cannot be done because there is not enough agricultural land and not suitable climate conditions for agriculture (GDF, 2015). Therefore, migration from the study area to big cities inetitable for the people (TUIK 2020a) The area has a rich plant diversity due to its location within the boundaries of the Irano-Turanian and Euro-Siberian flora regions. In the study area, 241 vascular plant taxa belonging to 66 families and 170 species which have medicinal and aromatic uses were determined (Onal 2012). In addition to different endemic species, the area includes some plant species on the IUCN Red List: Astragalus nigrocalycinus (CR-Critically Endangered), Psephellus taochius (EN-Endangered), and Delphinium munzianum (CR) (Eken et al. 2006). Also, many bird, fish, and mammal species are found in the planning unit (GDF, 2015). 


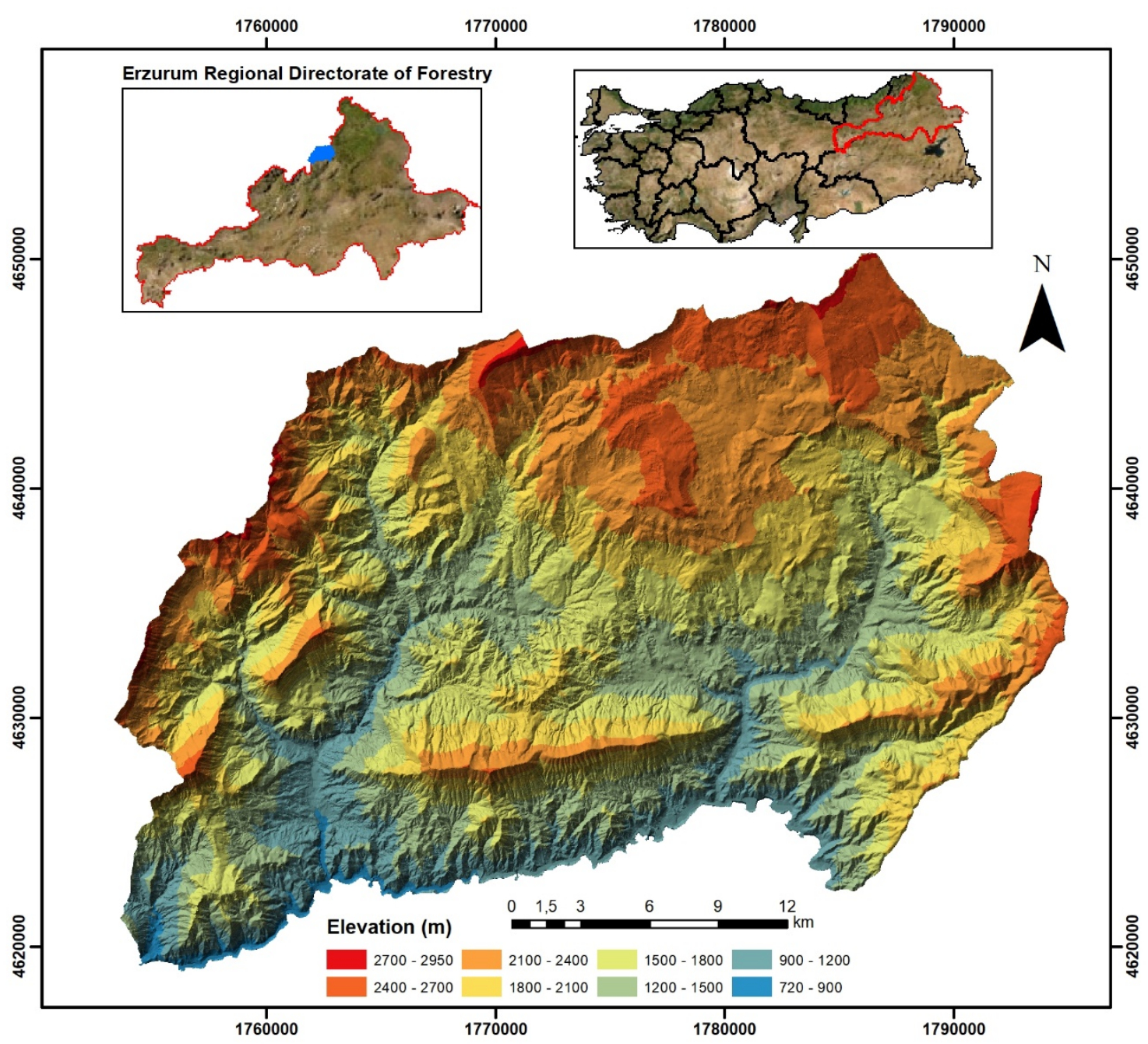

Figure 1. The location of the Olur forest planning unit.

\subsection{Database development}

To determine spatial and temporal changes of the Olur forest planning unit, forest cover type maps from 1970, 1998, and 2015 derived from the combination of RS data and field surveys were used. While the forest cover type map from 1970 was manually digitized creating a spatial database using Arc/Info $10^{\mathrm{TM}}$ with a maximum root mean square error under 5 meters, the digitized maps from 1998 and 2015 were obtained from the General Directorate of Forestry (GDF). After intersecting each database using the overlay function of Arc/Info, transition tables were created for the periods of 1970-1998 and 1970-2015 separately. Also, spatial configuration for selected landscape metrics was determined through Patch Analysis 5.0 between 1970-2015 for land use/cover classes. GNP and population information were obtained from the Turkish Statistical Institute (TUIK), and forest crime records were taken from the Olur Forest Enterprise (TUIK 2020a, b). Annual deforestation rates were calculated using the following compound-interest-rate formula due to its explicit biological meaning (Puyravaud, 2003):

$$
P=\frac{100}{t_{2}-t_{1}} \ln \frac{A_{2}}{A_{1}}
$$

where $P$ is the annual percentage of forest loss, and $A_{1}$ and $A_{2}$ are the numbers of forested areas at time $t_{1}$ and $t_{2}$, respectively. 


\section{Results}

\subsection{Temporal changes in land cover/land use cover classes}

Temporal changes in land use/land cover from 1970 to 2015 were determined based on the digitized forest cover type maps from forest management plans (Table 1). The total forest cover land increased from 19,382.7 ha in 1970 to $28,685.5$ ha in 2015 with a net increase of $48.0 \%$. However, non-forest areas with forest openings decreased from 61,359.6 ha (76.0\%) in 1970 to 52,176.0 ha (64.53\%) in 2015, accounting for 9183.6 ha (15.0\%). Over 45

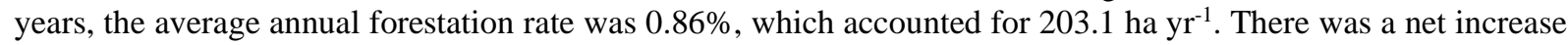
in pure forest areas by about 19.3\%, 13.8\% and 35.8\% during 1970-1998, 1998-2015, and 1970-2015, respectively. While degraded, non-forest, and mixed areas increased by about $120.6 \%, 46.1 \%$, and 100\%, respectively, coppice and forest openings decreased by about $100 \%$ and 21.2\%, respectively from 1970 to 2015.

Table 1. Changes in area (ha) of land cover/land use classes based on forest cover type maps

\begin{tabular}{lccccc}
\hline Land cover/land use & \multicolumn{3}{c}{ Years } & \multicolumn{3}{c}{ Differences (+/-) } \\
\cline { 2 - 6 } cover classes & $\mathbf{1 9 7 0}$ & $\mathbf{1 9 9 8}$ & $\mathbf{2 0 1 5}$ & $\mathbf{1 9 7 0 - 1 9 9 8}$ & $\mathbf{1 9 7 0 - 2 0 1 5}$ \\
\cline { 2 - 6 } & $\begin{array}{c}\text { Area } \\
\text { (ha) }\end{array}$ & $\begin{array}{c}\text { Area } \\
\text { (ha) }\end{array}$ & $\begin{array}{c}\text { Area } \\
\text { (ha) }\end{array}$ & \% & \% \\
\hline Pure forest & $5,338.67$ & $6,370.47$ & $7,251.03$ & 19.33 & 35.82 \\
Mixed forest & - & - & 165.53 & - & 100 \\
Coppice forest & $4,403.61$ & $3,825.46$ & - & -13.13 & 100 \\
Degraded forest & $9,640.39$ & $7,693.66$ & $21,268.91$ & 20.19 & 120.62 \\
Forest openings & $55,667.04$ & $25,908.50$ & $43,857.25$ & -53.45 & 21.21 \\
Non-forest & $5,692.58$ & $37,028.20$ & $8,318.79$ & 550.46 & 46.13 \\
\hline Total area & $\mathbf{8 0 , 7 4 2 . 2 9}$ & $\mathbf{8 0 , 8 2 6 . 2 8}$ & $\mathbf{8 0 , 8 6 1 . 5 1}$ & & \\
\hline
\end{tabular}

The transitions among land cover types from 1970 to 1998 and 2015 were obtained based on forest management plans to analyze changes in forest structure (Table 2, Table 3). The results showed that while 3,318.45 (62.16\%) ha of the pure forest areas remained unchanged, 2,020.21 ha of the pure forest changed into the coppice, degraded, forest openings, and non-forest areas accounting for 3.13\%, 9.05\%, 11.92\%, and 13.74\%, respectively in 1998 (Table 2). Also, pure areas that converted to degraded, forest openings, and mixed forest areas accounted for $19.16 \%, 14.53 \%$, and $0.3 \%$, respectively in 2015 (Table 3). While the coppice areas that changed into pure forest, degraded, forest openings, and non-forest areas accounted for 13.65\%, 24.33\%, 28.45\%, and 9.25\%, respectively in 1998, these areas completely changed into non-forest areas (85.75 ha), degraded (3,442.30 ha), forest openings (578.3 ha), and pure forest (278.5 ha) with a percentage of $1.96 \%, 78.5 \%, 13.19 \%$, and $6.36 \%$, respectively in 2015. Degraded areas contributed to high and productive forest lands by about $12.96 \%$ and $16.84 \%$ in 1998 and 2015, respectively, whereas $12.88 \%$ (1,240.89 ha) and $1.66 \%$ (159.82 ha) of these areas turned into non-forest areas in 1998 and 2015, respectively.

Table 2. Changes in area (ha) of land cover/land use classes between 1970-1998.

\begin{tabular}{|c|c|c|c|c|c|c|c|}
\hline \multirow{2}{*}{$\begin{array}{l}\text { Land cover } \\
\text { classes } \\
(1970)\end{array}$} & \multicolumn{7}{|c|}{ Land cover classes (1998) } \\
\hline & $\begin{array}{l}\text { Pure } \\
\text { forest }\end{array}$ & $\begin{array}{l}\text { Coppice } \\
\text { forest }\end{array}$ & $\begin{array}{l}\text { Degraded } \\
\text { forest }\end{array}$ & $\begin{array}{l}\text { Forest } \\
\text { openings }\end{array}$ & Non-forest & Agriculture & Total \\
\hline Pure forest & $3,318.45$ & 167.13 & 483.10 & 636.52 & 423.34 & 310.13 & $5,338.67$ \\
\hline $\begin{array}{l}\text { Coppice } \\
\text { forest }\end{array}$ & 598.38 & $1,066.53$ & $1,067.10$ & $1,247.46$ & 245.97 & 159.86 & $4,385.30$ \\
\hline $\begin{array}{l}\text { Degraded } \\
\text { forest }\end{array}$ & $1,249.36$ & $1,471.63$ & $3,900.58$ & $1,775.40$ & 743.60 & 497.29 & $9,637.86$ \\
\hline $\begin{array}{l}\text { Forest } \\
\text { openings }\end{array}$ & 938.21 & $1,005.64$ & $1,978.50$ & $20,460.51$ & $20,050.40$ & $10,869.80$ & $55,303.05$ \\
\hline Non-forest & 165.90 & 79.96 & 141.59 & $1,459.55$ & $1,232.24$ & 304.12 & 3,383.35 \\
\hline Agriculture & 49.11 & 33.98 & 66.67 & 266.01 & 585.75 & $1,280.47$ & $2,281.99$ \\
\hline Total & $6,319.40$ & $3,824.86$ & $7,637.54$ & $25,845.45$ & $23,281.30$ & $13,421.67$ & $80,330.22$ \\
\hline
\end{tabular}


There was a remarkable gain from the non-forest area in 1970 to forested areas in 1998 and 2015. The conversion of non-forest areas to degraded, high, and productive forest and coppice areas was about $4.18 \%, 4.9 \%$, and $2.36 \%$ in 1998 and 47.50\%, 4.80\%, and 0\% in 2015, respectively (Table 2, Table 3). Besides, agricultural areas converted to forested areas by about $6.56 \%$ and $18.29 \%$, respectively in 1998 and 2015 due to the abandonment of these areas. As such, a significant increase in forest areas can be associated with rehabilitation activities in degraded areas, afforestation activities in forest opening areas, and regeneration activities in the over-matured stands between 1970-2015.

Table 3. Changes in area (ha) of land cover/land use classes between 1970-2015.

\begin{tabular}{|c|c|c|c|c|c|c|c|}
\hline \multirow{2}{*}{$\begin{array}{l}\text { Land cover } \\
\text { classes } \\
(1970)\end{array}$} & \multicolumn{7}{|c|}{ Land cover classes (2015) } \\
\hline & $\begin{array}{l}\text { Pure } \\
\text { forest }\end{array}$ & $\begin{array}{l}\text { Mixed } \\
\text { forest }\end{array}$ & $\begin{array}{l}\text { Degraded } \\
\text { forest }\end{array}$ & $\begin{array}{l}\text { Forest } \\
\text { openings }\end{array}$ & $\begin{array}{l}\text { Non- } \\
\text { forest }\end{array}$ & Agriculture & Total \\
\hline Pure forest & $3,398.34$ & 15.97 & $1,022.92$ & 775.55 & 16.57 & 109.33 & $5,338.67$ \\
\hline $\begin{array}{l}\text { Coppice } \\
\text { forest }\end{array}$ & 278.95 & - & $3,442.30$ & 578.30 & 4.41 & 81.35 & $4,385.30$ \\
\hline $\begin{array}{l}\text { Degraded } \\
\text { forest }\end{array}$ & $1,523.20$ & 100.17 & $6,495.67$ & $1,358.99$ & 2.39 & 157.44 & $9,637.86$ \\
\hline $\begin{array}{l}\text { Forest } \\
\text { openings }\end{array}$ & $1,760.06$ & 49.32 & $8,229.78$ & $39,000.86$ & 184.15 & $6,078.88$ & $55,303.06$ \\
\hline Non-forest & 162.27 & - & $1,607.21$ & $1,093.38$ & 241.49 & 279.01 & 3,383.35 \\
\hline Agriculture & 67.52 & - & 349.84 & 839.40 & 207.77 & 817.46 & $2,281.99$ \\
\hline Total & $7,190.33$ & 165.45 & $21,147.72$ & $43,646.48$ & 656.77 & $7,523.46$ & $80,330.22$ \\
\hline
\end{tabular}

\subsection{Temporal changes in canopy cover}

To detect structured changes in forest dynamics, forest cover type type maps were examined in terms of crown closure. Unlike low and medium coverage areas, regenerated and full coverage areas increased by $498 \%$ and 42.26\%, respectively from 1970 to 2015 (Table 4). Changes of crown closure over 45 years showed that fully covered stands and degraded areas significantly increased whereas low and medium covered stands decreased.

Table 4. Changes of canopy cover classes for each period.

\begin{tabular}{llllll}
\hline & \multicolumn{2}{l}{ Years } & & \multicolumn{2}{c}{ Differences (+/-) } \\
\cline { 2 - 6 } $\begin{array}{l}\text { Canopy cover } \\
\text { (Criteria \% cover) }\end{array}$ & $\mathbf{1 9 7 0}$ & $\mathbf{1 9 9 8}$ & $\mathbf{2 0 1 5}$ & $\mathbf{1 9 7 0 - 1 9 9 8}$ & $\mathbf{1 9 7 0 - 2 0 1 5}$ \\
\cline { 2 - 6 } & $\begin{array}{l}\text { Area } \\
\text { (ha) }\end{array}$ & $\begin{array}{l}\text { Area } \\
\text { (ha) }\end{array}$ & $\begin{array}{l}\text { Area } \\
\text { (ha) }\end{array}$ & \% & \% \\
\hline Regenerated & 258.87 & $1,070.64$ & $1,548.04$ & 313.57 & 498 \\
$\mathbf{1}$ (low coverage, 11\%-40\%) & 645.76 & 588.23 & 542.16 & -8.91 & -16.04 \\
$\mathbf{2}$ (medium coverage, $\mathbf{4 1 \% - 7 0 \% )}$ & $1,409.68$ & $1,433.06$ & $1,023.81$ & 1.66 & -27.37 \\
$\mathbf{3}$ (full coverage, $>\mathbf{7 1 \% )}$ & $3,024.35$ & $3,626.44$ & $4,302.54$ & 19.91 & 42.26 \\
Coppice forest & $4,403.61$ & $3,477.57$ & - & 21.03 & -100 \\
Degraded forest & $9,640.39$ & $7,693.66$ & $21,268.91$ & -20.19 & 120.62 \\
Non-forest & $61,359.62$ & $62,936.7$ & $52,176.05$ & 2.57 & 14.97 \\
\hline Total & $\mathbf{8 0 , 7 4 2 . 2 9}$ & $\mathbf{8 0 , 8 2 6 . 2 8}$ & $\mathbf{8 0 , 8 6 1 . 5 1}$ & & \\
\hline
\end{tabular}

While covered areas transitioning to the status of degraded indicate that the forest structure has deteriorated, covered areas evolving into fully covered areas show that the forest structure has improved. The conversion of the regenerated, low covered, and medium covered areas to more covered areas accounting for $51.30 \%, 69.56 \%$, and $60.17 \%$, respectively had a positive effect on forest structure. Besides, the conversion of coppice, degraded, and non-forest areas to high and productive areas from 1970 to 2015 by about $6.36 \%, 16.84 \%$, and $11.03 \%$, respectively contributed to a positive impact on forest structure (Table 5). These conversions on canopy cover based on silvicultural interventions and forest growth resulted in a more stable forest structure. Although the increase in degraded areas is considered a negative situation in terms of forest structure because the main reason for this 
increase in the degraded areas is the transition of non-forest areas and coppice areas to degraded areas, it is a positive situation.

Table 5. Change in area (ha) of canopy cover classes based on forest t cover maps.

\begin{tabular}{llllllll}
\hline $\begin{array}{l}\text { Crown closure } \\
\text { classes } \\
(\mathbf{1 9 7 0 )}\end{array}$ & \multicolumn{2}{l}{ Crown closure (2015) } \\
\cline { 2 - 8 } & $\begin{array}{l}\text { Regener } \\
\text { ated }\end{array}$ & $\mathbf{1}$ & $\mathbf{2}$ & $\mathbf{3}$ & $\begin{array}{l}\text { Degraded } \\
\text { forest }\end{array}$ & $\begin{array}{l}\text { Non- } \\
\text { forest }\end{array}$ & Total \\
\hline Regenerated & 7.00 & 5.54 & 32.81 & 94.43 & 91.78 & 27.31 & $\mathbf{2 5 8 . 8 7}$ \\
$\mathbf{1}$ & 15.49 & 24.75 & 120.93 & 328.28 & 127.88 & 28.43 & $\mathbf{6 4 5 . 7 6}$ \\
$\mathbf{2}$ & 25.83 & 83.75 & 178.00 & 848.20 & 209.54 & 64.37 & $\mathbf{1 , 4 0 9 . 6 8}$ \\
$\mathbf{3}$ & 25.13 & 104.53 & 98.64 & $1,420.99$ & 593.72 & 781.35 & $\mathbf{3 , 0 2 4 . 3 6}$ \\
Coppice forest & 57.66 & 56.04 & 19.02 & 146.23 & $3,442.30$ & 664.06 & $\mathbf{4 , 3 8 5 . 3 0}$ \\
Degraded forest & 444.51 & 136.28 & 274.92 & 767.66 & $6,495.67$ & $1,518.81$ & $\mathbf{9 , 6 3 7 . 8 6}$ \\
Non-forest & 969.87 & 120.46 & 293.16 & 655.67 & $10,186.83$ & $48,742.39$ & $\mathbf{6 0 , 9 6 8 . 3 9}$ \\
\hline Total & $\mathbf{1 , 5 4 5 . 4 9}$ & $\mathbf{5 3 1 . 3 5}$ & $\mathbf{1 , 0 1 7 . 4 8}$ & $\mathbf{4 , 2 6 1 . 4 6}$ & $\mathbf{2 1 , 1 4 7 . 7 2}$ & $\mathbf{5 1 , 8 2 6 . 7 2}$ & $\mathbf{8 0 , 3 3 0 . 2 2}$ \\
\hline
\end{tabular}

\subsection{Temporal changes in development stages}

To evaluate the change in the quality of forest structure, further analysis was conducted on the development stages of forest ecosystems. Whereas high and productive forests were generally clumped into the development stage $b$ (young) with 4,470.03 ha in 1970, the areas were mostly concentrated into the stages b (young) and c (mature) with 5,845.30 ha in 2015. These results showed that productive forest areas mostly changed to young and mature development stages. On the other hand, the increase in the regenerated areas by about 313.58\% (811.77 ha) in 1998 and 498\% (1,289.17 ha) in 2015 was a positive development for sustainable forestry (Table 6).

Table 6. Changes in development stage classes based on forest cover type maps.

\begin{tabular}{llllll}
\hline $\begin{array}{l}\text { Development stages } \\
\text { (Criteria, average }\end{array}$ & Years & & & \multicolumn{2}{l}{ Differences (+/-) } \\
\cline { 2 - 6 } dbh) & $\mathbf{1 9 7 0}$ & $\mathbf{1 9 9 8}$ & $\mathbf{2 0 1 5}$ & $\mathbf{1 9 7 0 - 1 9 9 8}$ & $\mathbf{1 9 7 0 - 2 0 1 5}$ \\
\cline { 2 - 6 } & $\begin{array}{l}\text { Area } \\
\text { (ha) }\end{array}$ & $\begin{array}{l}\text { Area } \\
\text { (ha) }\end{array}$ & $\begin{array}{l}\text { Area } \\
\text { (ha) }\end{array}$ & $\mathbf{\%}$ & $\mathbf{\%}$ \\
\hline a (regenerated, $<\mathbf{8})$ & 258.87 & $1,070.64$ & $1,548.04$ & 313.58 & 498 \\
b (young, 8-19.9) & $4,470.03$ & $3,138.07$ & $3,247.95$ & -29.80 & 27.34 \\
c (mature, 20-35.9) & - & $1,884.63$ & $2,597.35$ & 100 & 100 \\
d (over-mature, >36) & 609.77 & 277.13 & 23.22 & -54.55 & -96.20 \\
Coppice forest & $4,403.61$ & $3,825.46$ & - & -13.13 & -100 \\
Degraded forest & $9,640.39$ & $7,693.66$ & $21,268.91$ & -20.19 & 120.62 \\
Non-Forest & $61,359.62$ & $62,936.70$ & $52,176.04$ & 2.57 & -14.97 \\
\hline Total area & $\mathbf{8 0 , 7 4 2 . 2 9}$ & $\mathbf{8 0 , 8 2 6 , 2 8}$ & $\mathbf{8 0 , 8 6 1 . 5 1}$ & & \\
\hline
\end{tabular}

While about 83 ha (32.06\%) and 49.79 ha (19.24\%) of regenerated areas grew naturally into the young and mature development stages, respectively, 1,114.38 ha (24.93\%) of the areas in the young development stage converted to the mature development stage. Also, the areas in the over-mature stage that converted to the regenerated, young, and mature stages accounted for 11.17 ha (1.83\%), 137.54 ha (22.56\%), and 370.89 ha (60.82\%), respectively, possibly through regeneration activities (Table 7). Over 45 years, there was a net increase of 1,286.61 ha for regenerated areas with the highest contribution from non-forest and degraded areas by about $91.52 \%(1,414.39$ ha). Besides, the conversion of degraded areas, coppice, and non-forest areas to high and productive areas accounting for 1623.37 ha (16.84\%), 278.95 ha (6.36\%), and 2039.16 ha (3.34\%), respectively led to an increase in the quality of forest structure. 
Table 7. Change in area (ha) of development stage classes between 1970-2015.

\begin{tabular}{llllllll}
\hline $\begin{array}{l}\text { Development } \\
\text { stages } \\
(\mathbf{1 9 7 0 )}\end{array}$ & \multicolumn{6}{l}{ Development stages (2015) } \\
\cline { 2 - 8 } & $\mathbf{a}$ & $\mathbf{b}$ & $\mathbf{c}$ & $\mathbf{d}$ & $\begin{array}{l}\text { Degraded } \\
\text { forest }\end{array}$ & Non-forest & Total \\
\hline $\mathbf{a}$ & 7.00 & 83.00 & 49.79 & - & 91.78 & 27.31 & $\mathbf{2 5 8 . 8 8}$ \\
$\mathbf{b}$ & 55.27 & $1,572.51$ & $1,114.38$ & - & 898.68 & 829.19 & $\mathbf{4 , 4 7 0 . 0 3}$ \\
$\mathbf{d}$ & 11.17 & 137.54 & 370.89 & 12.76 & 32.46 & 44.95 & $\mathbf{6 0 9 . 7 7}$ \\
Degraded forest & 444.51 & 852.43 & 322.51 & 3.92 & $6,495.67$ & $1,518.81$ & $\mathbf{9 , 6 3 7 . 8 5}$ \\
Coppice forest & 57.66 & 180.51 & 40.78 & - & $3,442.30$ & 664.06 & $\mathbf{4 , 3 8 5 . 3 1}$ \\
Non-forest & 969.87 & 413.51 & 649.26 & 6.52 & $10,186.83$ & $48,742.39$ & $\mathbf{6 0 , 9 6 8 . 3 8}$ \\
\hline Total & $\mathbf{1 , 5 4 5 . 4 8}$ & $\mathbf{3 , 2 3 9 . 5}$ & $\mathbf{2 , 5 4 7 . 6 1}$ & $\mathbf{2 3 . 2}$ & $\mathbf{2 1 , 1 4 7 . 7 2}$ & $\mathbf{5 1 , 8 2 6 . 7 1}$ & $\mathbf{8 0 , 3 3 0 . 2 2}$ \\
\hline
\end{tabular}

\subsection{Change in forestation/deforestation rate}

The forestation improvement or deforestation rate over 45 years (1970-2015) was calculated as $0.87 \%$ and $0.73 \%$ for the degraded and productive forests combined and for only the productive forests, respectively. All these changes indicated that the forests in general, including productive forests, increased substantially.

\subsection{Spatial analysis of change in forest structure}

The spatial analysis of the landscape pattern based on all land use classes indicated that the total NP, the edge density (ED), and the area-weighted mean shape index (AWMSI) increased by about 51.07\%, 44.86\%, and 3.56\%, respectively during the 40 -year period. However, the mean patch size (MPS) decreased by about $23 \%$ between 1970 and 2015 when all land cover types were taken into account. Similarly, when all land cover types were evaluated separately, almost all cover types showed the same changes as total changes (Table 8). All these changes over 45 years clearly indicated that the forest landscape fragmentation increased, and patches became edgier, thereby increasing forest susceptibility to further deterioration in the future. One of the most detrimental consequences of fragmentation is creating isolation between forest communities, resulting in the restriction of the movement of animals and plants. Because ecosystem fragmentation can cause interruption of breeding and gene flow in plant and animal communities, species diversity, composition, abundance, distribution, and biotic interactions change in important ways over the long term (Benitez-Maldiva and Rodrigez, 2008).

Table 8. Changes in landscape pattern between 1970-2015.

\begin{tabular}{|c|c|c|c|c|c|c|c|c|c|c|}
\hline \multirow[t]{2}{*}{ Land covers } & \multicolumn{2}{|l|}{ NP } & \multicolumn{2}{|c|}{ MPS (ha) } & \multicolumn{2}{|l|}{ ED } & \multicolumn{2}{|l|}{ MSI } & \multicolumn{2}{|c|}{ AWMSI } \\
\hline & 1970 & 2015 & 1970 & 2015 & 1970 & 2015 & 1970 & 2015 & 1970 & 2015 \\
\hline Pure forest & 382 & 595 & 13,96 & 12.19 & 8.81 & 14.01 & 1.66 & 1.72 & 1.67 & 1.79 \\
\hline $\begin{array}{l}\text { Coppice } \\
\text { forest }\end{array}$ & 96 & - & 45.87 & - & 4.01 & - & 1.71 & - & 1.70 & - \\
\hline $\begin{array}{l}\text { Degraded } \\
\text { forest }\end{array}$ & 307 & 707 & 31.40 & 30.01 & 10.65 & 24.69 & 1.74 & 1.73 & 1.72 & 1.67 \\
\hline $\begin{array}{l}\text { Forest } \\
\text { openings }\end{array}$ & 402 & 428 & 138.49 & 102.46 & 26.31 & 25.77 & 1.77 & 1.77 & 1.70 & 1.81 \\
\hline Agriculture & 107 & 292 & 21.44 & 26.17 & 3.57 & 10.41 & 1.84 & 1.91 & 2.01 & 2.29 \\
\hline Non-forest & 149 & 143 & 22.80 & 4.72 & 3.58 & 1.71 & 1.38 & 1.39 & 1.61 & 1.47 \\
\hline Mixed forest & - & 15 & - & 11.01 & - & 0.30 & - & 1.51 & - & 1.55 \\
\hline Total & 1,443 & 2,180 & 273.96 & 186.56 & 56.93 & 76.89 & 10.1 & 10.03 & 10.41 & 10.58 \\
\hline
\end{tabular}

\section{Discussion and Conclusion}

The study analyzed the spatial change of forest structure in the Olur forest planning unit between 1970 to 2015 based on land use/land cover classes, canopy cover, and development stages taking into consideration some distinct socio-economic factors including forest crime rates, rural population change, and annual GNP. It is clear that these 
factors have a significant impact on changes in forest ecosystems. Forest villagers are the main components of rural populations in forest land, and $99.9 \%$ of forest land is managed by the state in Turkey. In this case, serious problems will inevitably arise in terms of anthropogenic interventions such as illegal utilization, clearing, or burning for agricultural use and grazing. As forest ecosystems are sensitive to this intervention, they are affected negatively, and natural composition, biodiversity, and resilience are damaged. As such, it is crucial to analyze the ecological consequences of forest dynamics in terms of socio-economic factors.

\subsection{Temporal change}

There was a net increase of 9,141.67 ha in total forested areas due to afforestation in the study area. In other words, of the non-forest areas existing in 1970, almost 3.34\% converted to high and productive forest areas, and $16.71 \%$ converted to degraded areas in 2015. Besides, degraded areas showed a significant increase due to the conversion of non-forest areas with afforestation. According to all transitions between land cover/land use classes between 1970-1998 and 1970-2015 (Figure 2, while transition percentages from total forest cover land to non-forest and degraded areas were $25.66 \%$ (1,369.9 ha) and $11.4 \%$ (608.85 ha) between 1970-1998, they were $16.89 \%$ (901.45 ha) and 19.16\% (1,022.92 ha) between 1970-2015, respectively. Total forest cover land gained 2,039.23 ha (27.72\%) and 1,903.23 ha (13.57\%) from non-forest and degraded areas, respectively between 1970 and 2015. These transitions were attributed to an increase in total forest cover land.

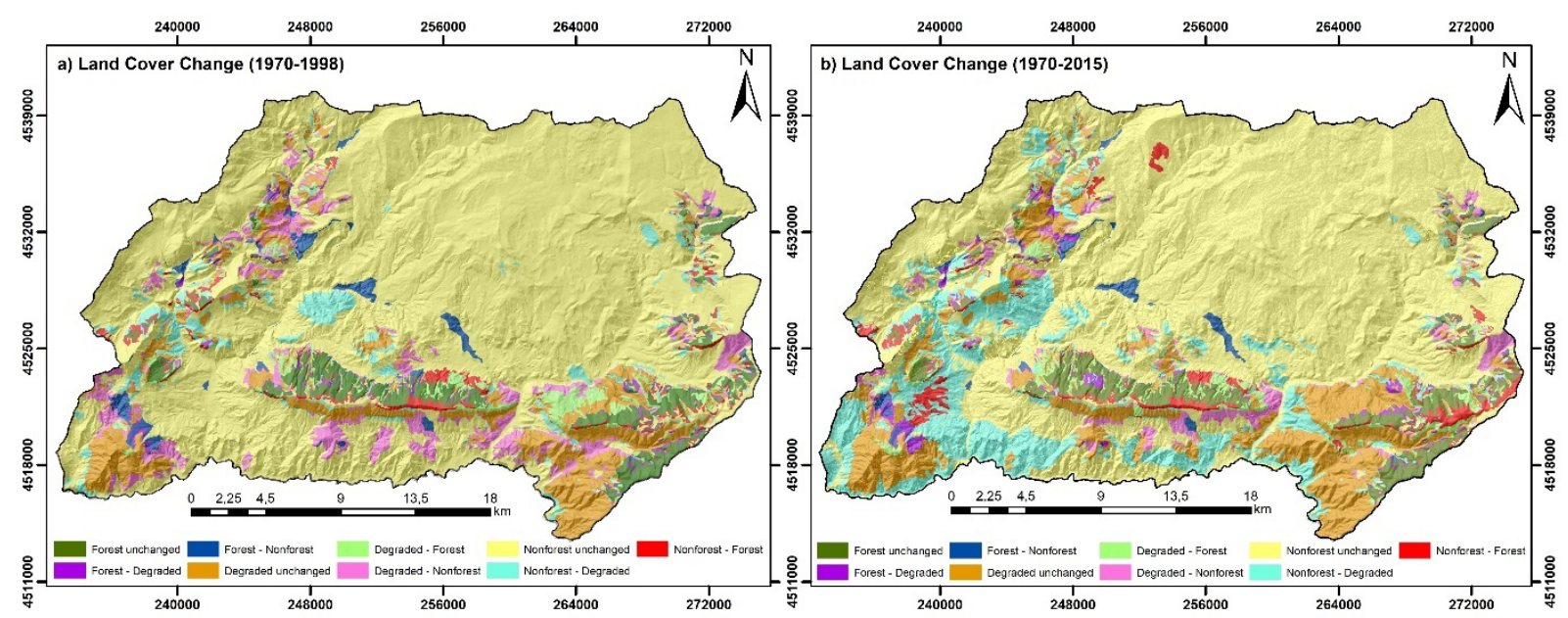

Figure 2. Land use/land cover class transitions between 1970-1998 and 1970-2015.

The increasing degraded areas and decreasing non-forest areas in the Olur forest planning unit could be explained by the following reasons. First, afforestation applications under some actions on degraded areas and forest openings contributed to the increase in the forest area. The increase in the forested areas can be mainly obtained by afforestation activities on forest openings and degraded areas to control soil erosion and afforestation of abandoned agricultural lands in the study area. According to the national forestry policy in Turkey, GDF has been implementing the Forest Conversion Action Plan with the aim of converting the coppice stands to the high forest since 2006 (GDF, 2006b). Coppice stands were managed by a short rotation period causing a major threat to the maintenance of biological diversity. In this context, coppice stands were started to be converted to high forests through different silvicultural treatments. While the total coppice forest area was 5.75 million ha (27.1\%) in 2005, it decreased to 1.2 million ha (5.3\%) as of 2018 in the total forest land in Turkey (GDF, 2018). In this way, a significant increase has been achieved in high forest areas. Also, after the implementation of the National Afforestation and Erosion Control Action Plan in 2008, GDF made afforestation, rehabilitation, and artificial regeneration activities in the degraded areas for erosion control (GDF, 2008). These action plans led to a significant increase in forested areas.

Second, in the study area, population density dramatically decreased over four decades. The rural population decreased from 18,313 in 1970 to 4,005 in 2019 with a reduction of $78 \%$. It is the result of migration from rural to urban areas and contributed to the increase in the forest area by decreasing social pressure on forests. Several studies also indicated that population density affects land use and land cover type changes. Sivrikaya et al. (2007a) reported that productive forest areas increased by 850.8 ha (3\%), and the population decreased by $61.1 \%$ from 1972 to 2005 in the Camili forest planning unit, which is located in northeastern Turkey. Similarly, Cakir et al. 
(2008a) showed that forested areas increased by 1,189 ha (4.2\%), and the rural population decreased by $17.8 \%$ from 1975 to 2000 in the Macka State Forest Enterprise located in the East Black Sea Region of Turkey. Besides, Bozali et al. (2015) and Keles et al. (2016) indicated that forest cover lands significantly increased by 1,974.5 ha (9.7\%) and 3,356 ha (36.4\%) over about two decades in the Baskonus and Golyaka forest planning units, respectively.

\subsection{Effect of socioeconomic factors on forest ecosystems}

The impacts of some socio-economic factors such as rural population, forest crime rates, and per capita income were also taken into account in the study area, and similar trends were obtained. The rural population changed from 18,313 in 1970 to 4,015 in 2019 (TUIK 2020a). In other words, the population of Olur decreased by nearly $78 \%$ over 49 years. As a result of the decrease in the rural population between 1970-2019, a serious decline was observed in forest crime records except 2011 (Figure 3). General election of Turkey in 2011 can be related with the reason for a partial increase in forest crimes in this year. This change between 1970-2019 showed that a decrease in the population can lead to a decrease in human pressure on forest areas, probably resulting in the positive development of forest areas (Karanth et al. 2006).

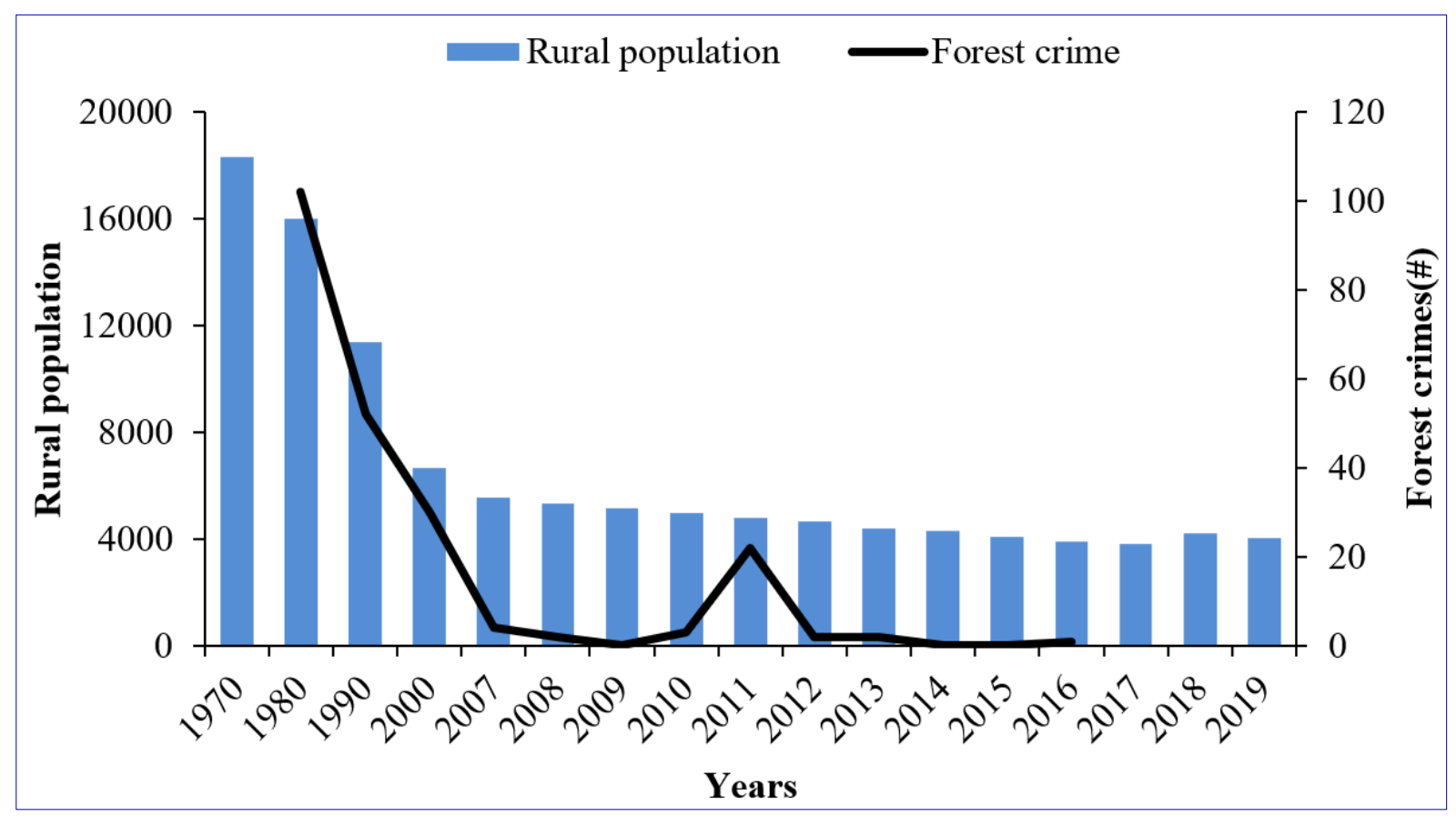

Figure 3. Relationship between the rural population and forest crime record.

In addition, the relationship between forest crime records and average per capita income was evaluated. Forest crimes decreased from 160 in 1979 to 0 in 2018. However, GNP in Erzurum province increased from \$ 3,058 in 2004 to \$ 5,706 in 2018 with an increase of 87\% (TUIK 2020b) (Figure 4). The inverse relationship between GNP and forest crime records demonstrated that environmental awareness of society increased over time based on the welfare level as the environmental Kuznets curves hypothesis emphasized (Mather et al. 1999b). As a result, the pressure on forest ecosystems tended to decrease gradually, and forested areas increased. The main reason for this increase is the conversion of abandoned agricultural lands into forest areas as a result of the decrease in population. The decrease in population and the increase in the educational and economic conditions of the people have contributed greatly to the sensitivity of the society by changing the perspective on the forest. The serious reduction of forest crime rates is a clear result of this change in the perspective of society.

Forest villagers are the main components of the rural population, and approximately 99.9\% of forest land is managed by the state in Turkey. In this case, serious problems will inevitably arise in terms of anthropogenic interventions which cause forest crimes including logging the forest trees, the transference of forestry products without permission, expanding lands and occupied land in the forest, and expending forest products and pasturage without permission, all of which are major ecological and economic threats to forest ecosystems. Between 19882018, a total of 776,239 forest crimes were recorded in Turkey (GDF, 2018). There was a loss of $1.29 \mathrm{million} \mathrm{m}^{3}$ solely due to illegal logging of forest trees during this period. However, there was a considerable decline in total forest crime rates, decreasing by 73.4\% from 41,845 in 1988 to 11,112 in 2018. 


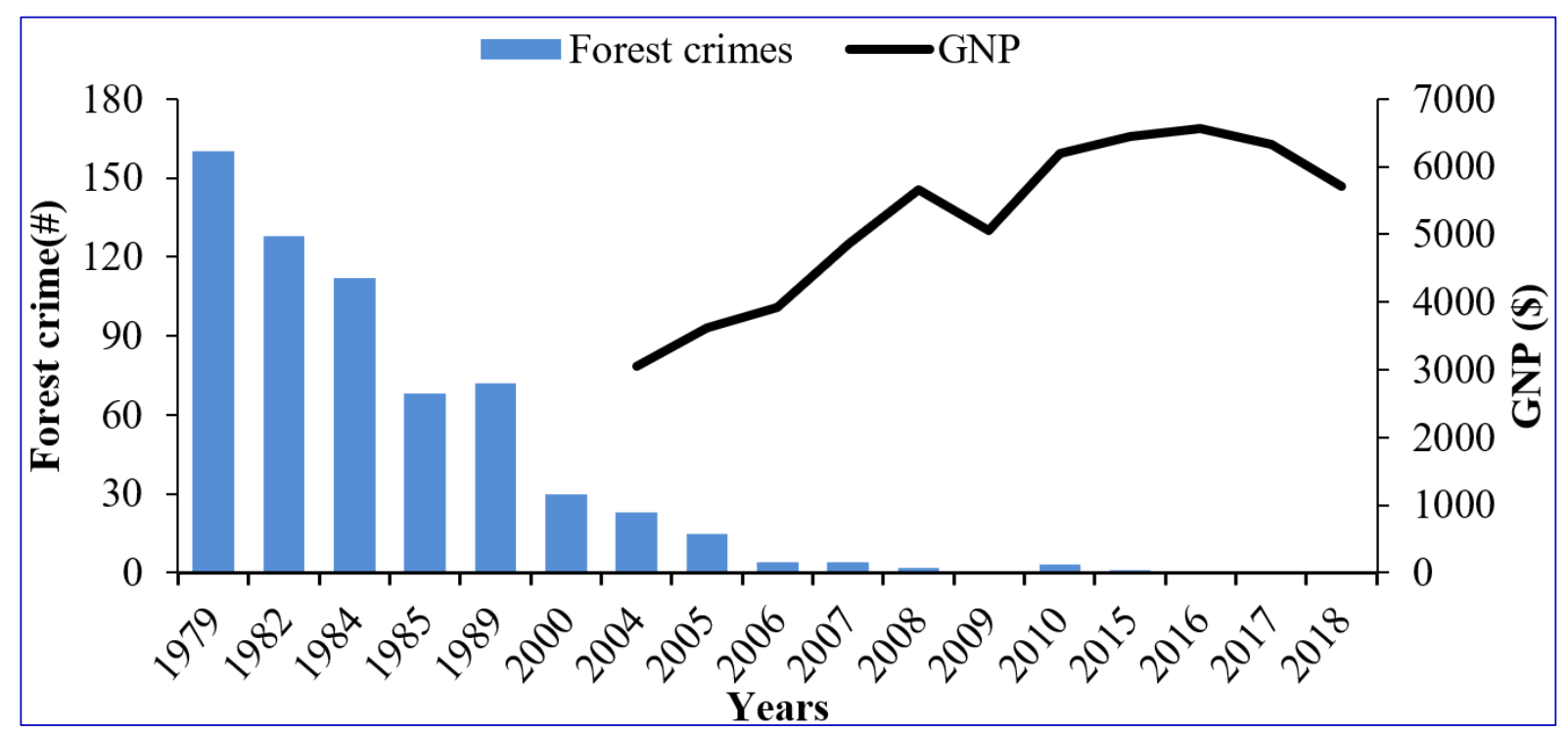

Figure 4. Relationship between per capita income and forest crime record.

Due to employment problems and limited social and educational opportunities, there has been intense immigration from rural areas to urban areas in recent decades, and this serious reduction in forest crime is closely related to the continuous decrease in rural population density. This decrease in rural population density and gradual increase in urban population are the main results of urbanization.

\subsection{Spatial change}

The spatial analysis of the landscape pattern indicated that the number of fragments and isolation of patches increased, and the MPS decreased; thus, the forest gradually turned into a more fragmented structure (Figure 5). As previously shown in Table 8, the total NP increased from 1,574 to 2,337 (42.12\%), and MPS decreased from 258.30 to 180.84 (29.99\%). The patch area sizes were classified into 3 main categories as class I ( $<25$ ha), class II (25-50 ha), and class III (>50 ha) to make a more detailed land fragmentation analysis (Figure 5). According to that, NP and patch size area increased by 53.23\% (511), 47.88\% (3,501,28 ha), and 86\% (166) 89.42\% (6,120.37 ha) in class I and II from 1970 to 2015, respectively. While NP increased by 20.69\% (60), the patch size area decreased by 14.26\% (9,492.67 ha) in class III. In forested areas, NP and patch size area from 1970 to 2015 increased by $63.72 \%$ (202) and 63.94\% (1,576.74 ha) in class I and by 50\% (27) and 57.31\% (993.39 ha) in class II, respectively. However, NP and patch size area from 1970 to 2015 decreased in class III by $43.16 \%$ (485.87 ha) and $9.09 \%$ (1), respectively. This change in the forest structure highlighted a danger for the sustainability of forest resources.

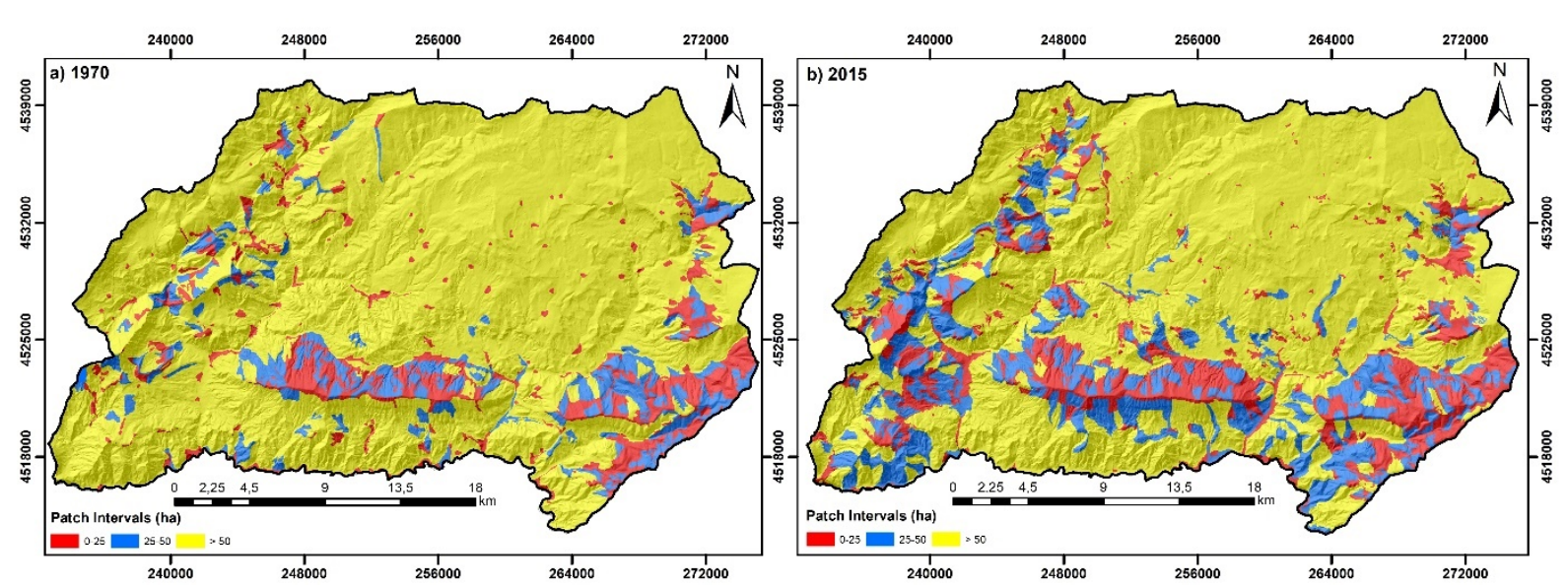

Figure 5. The spatial change of landscape fragmentation over 45 years. 
All these changes over about 45 years indicated that the forest landscape fragmentation increased, and patches became edgier, thereby increasing forest susceptibility to further deterioration in the future. Besides, forest fragmentation caused an increase in the number of edges in the landscape. As it is understood, edge effects have a critical impact on environmental (e.g., light, radiation, moisture, temperature, wind, and soil nutrients) and biological (e.g., species composition, competition, predation) changes along and close to the edge. Moreover, forest edges are the entry point of external influences such as fire, invasive species, pests, and pathogens to the fragmented patches (Benitez-Maldiva and Rodrigez, 2008). Some previous studies that concentrated on forest fragmentation in Turkish ecosystems showed similar results (Sivrikaya et al. 2007a; Keles et al. 2008; Cakir et al. 2008a; Gunlu et al. 2009; Bozali et al. 2015). In these studies, NP increased by $253.5 \%$, 87\%, 32.8\%, 36.4\%, and 190.6\%, unlike the MPS which decreased by $71.7 \%$, 46.5\%, 25\%, 70.7\%, and $65.7 \%$, respectively.

Although the forested areas increased remarkably in the study area, the spatial quality of forest landscape or fragmentation increased. The spatial degradation in the Olur planning unit developed in the form of conversion of some forest types and isolation of forest fragments. The main reasons for this degradation can be explained by nonconvenient forest management interventions and soil erosion. For this reason, the silvicultural interventions to reduce fragmentation should be envisaged, and the spatial parameters should be taken into account in forest management plans.

In conclusion, monitoring and evaluating spatiotemporal changes in forest ecosystems are very important because land-use changes directly affect the composition and configuration of forest ecosystems. Although the forested areas increase in the study area, the spatial quality based on the natural composition and configuration of forest landscape provides unfavorable habitats for biodiversity. Further, forest management practices are not practical and economical when patches become smaller as a result of fragmentation. Therefore, quantifiable and equitable evaluation of spatial composition and configuration of a landscape is very important for landscape management. Additionally, forest management interventions affect the status of forest ecosystems and biodiversity; thus, determining appropriate forest management decisions and policies is crucial to prevent fragmentation in forest ecosystems and to protect and monitor plant biodiversity. As a result, understanding the effects of the spatiotemporal changes in forest dynamics should be observed carefully in better planning management strategies for sustainable production and conservation of forest resources.

\section{References}

1. Akay, A.E., Sivrikaya, F., Gulci, S. (2014). Analyzing riparian forest cover changes along the Firniz River in the Mediterranean City of Kahramanmaras in Turkey. Environ Monit Assess 186:2741-2747.

2. Armenteras, D., Gast, F., Villareal, H. (2003). Andean forest fragmentation and the representativeness of protected natural areas in the eastern Andes, Colombia. Biol Conserv 113:245-256.

3. Armenteras, D., Rudas, G., Rodriguez, N., Sua, S., Romero, M. (2006). Pattern and cause of deforestation in Columbian Amazon. Ecol Indic 6:353-368.

4. Baskent, E.Z., Jordan, J.A. (1995). Characterizing spatial structure of forest landscapes: a hierarchical approach. Can J Forest Res 25:1830-1849.

5. Beier, P., Drielen, M.V., Kankam, B. (2002). Avifaunal collapse in West African forest fragments. Conserv Biol 16:1097-1111.

6. Benitez-Malvido, J., Arroyo-Rodriguez, V. (2008). Habitat fragmentation, edge effects and biological corridors in tropical ecosystems. Encyclopedia of Life Support Systems.

7. Bozali, N., Sivrikaya, F., Akay, A.E. (2015). Use of spatial pattern analysis to assess forest cover changes in the Mediterranean region of Turkey. J For Res 20:365-374.

8. Bozali, Nuri. (2021). Temporal dynamics in land use/land cover change: an example of kökez planning unit. Turk J For Sci. 5: 127-138.

9. Cakir, G., Sivrikaya, F., Keles, S. (2008a). Forest cover change and fragmentation using Landsat data in Macka State Forest Enterprise in Turkey. Environ Monit Assess 137:51-66.

10. Cakir, G., Latif, G., Aybar, M., Yılmaz, M. (2015). Evaluation of the land covers changes with socioeconomic conditions: case of Sebinkarahisar. Macadesu 2015, 1st International Conference on Sea and Coastal Development in the Frame of Sustainability, vol.1, no.1, Trabzon, Turkey.

11. Cayuela, L., Rey Benayas, J.M., Echeverria, C. (2006). Clearance and fragmentation of tropical montane forests in the Highlands of Chiapas, Mexico (1975-2000). For Ecol Manag 226:208-218.

12. Cernusca, A., Tappeiner, U., Bayfield, N. (1999). Land-Use Changes in European Mountain Ecosystems. ECOMONT-Concept and Results. Blackwell: Berlin, Germany. 
13. Chaves, M.E., Arango, N. (Eds.) (1998). Informe nacional sobre el estado de la biodiversidad 1997. Instituto de Investigación de Recursos Biológicos Alexander von Humboldt, PNUMA and Ministerio de Medio Ambiente. 3 vol. Bogotá, Colombia.

14. Chen, L., Wang, J., Fu, B., Qiu, Y. (2001). Land use change in a small catchment of northern loess Plateau, China. Agric Ecosyst Environ 86:163-172.

15. Debinski, D., Holt, R. (2000). A survey and overview of habitat fragmentation experiments. Conserv Biol 14:342-355.

16. DiBari, J.N. (2007). Evaluation of five landscape-level metrics for measuring the effects of urbanization on landscape structure: The case of Tucson, Arizona, Az. Landscape Urban Plan 79:308-313.

17. Doygun, H., Alphan, H. (2006). Monitoring urbanization of Iskenderun, Turkey and its negative implications. Environ Monit Assess 114:145-155.

18. Echeverria, C., Coomes, D., Salas, J., Rey-Benayas, J.M., Lara, A., Newton, A. (2006). Rapid deforestation and fragmentation of Chilean temperate forests. Biol Conserv 130:481-494.

19. Eken, G., Bozdogan, M.,Isfendiyaroglu, S., Kilİc, iD.T., Lise, Y. (eds) (2006). Key biodiversity areas of Turkey. Doga Dernegi, Ankara.

20. FAO (2015a). Global Forest Resources Assessment 2015: How are the world's forests changing? Second Edition. Rome.

21. Forman, R.T.T., Godron, M. (1986). Landscape Ecology. John Wiley: New York, NY.

22. Forman, R.T.T. (1995). Some general principles of landscape and regional ecology. Landscape Ecology 10 : 133-142.

23. García-Gigorro, S., Saura, S. (2005). Forest fragmentation estimated from remotely sensed data: Is comparison across scales possible? Forest Sci 51:51-63.

24. Gautam, A.P., Webb, E.L., Shivakoti, G.P., Zoebisch, M.A. (2003). Land use dynamics and landscape change pattern in a mountain watershed in Nepal. Agric Ecosyst Environ 99:83-96.

25. Grimm, N. B., Faeth, S. H., Golubiewski, N. E., Redman, C. L., Wu, J. G., Bai, X. M., et al. (2008). Global change and the ecology of cities. Science, 319(5864), 756-760.

26. GDF (2006a). Forest rehabilitation action plan. General Directorate of Forestry, Ankara, p 38.

27. GDF (2006b). Forest conversion action plan from coppice forest to high forest, 2006-2015. General Directorate of Forestry, Ankara, p 14.

28. GDF (2008). National Afforestation and Erosion Control Action Plan, 2008-2012. General Directorate of Forestry, Ankara, p 54.

29. GDF (2015). Erzurum Regional Directorate of Forestry, Olur State Forest Enterprise, Forest Management Plan for Olur Forest Planning Unit (2015-2034), Ankara.

30. Gibson, D.W., Wilson, J.D., Green, R.E. (2011). Using conservation science to solve conservation problems. J Appl Ecol 48:505-508.

31. Gigord, L., Picot, F., Shykoff, J.A. (1999). Effects of habitat fragmentation on Dombeya acutangula (Sterculiaceae), a native tree on La Réunion (Indian Ocean). Biol Conserv 88:43-51.

32. Gol, Ceyhun., Günlü, Alkan., Edis, Semih., Kucukdongul, Ahmet. (2018). The effects of catchment melioration on land use types and land cover (LULC) between 1990 - 2014 in Çorum - Osmancık - Emine Creek watersheds. Turk J For. 19: 149-155

33. Gunlu, A., Kadiogullari, A.I., Keles, S., Baskent, E.Z. (2009). Spatiotemporal changes of landscape pattern in response to deforestation in Northeastern Turkey: a case study in Rize. Environ Monit Assess 148:127137.

34. Halpern, C.B., Spies, T.A. (1995). Plant species diversity in natural and managed forests of the Pacific Northwest. Ecol Appl 5: 913-934.

35. Hietala-Koivu, R. (1999). Agricultural landscape change: a case study in Ylane, southwest Finland. Landscape Urban Plan 46:103-108.

36. Holdgate, M.V. (1993). The sustainable use of tourism: A key conservation issue. Ambio, 22: 481-484.

37. Houghton R.A. (1994). The worldwide extent of land-use change. BioScience 44: 305-313.

38. Imbernon, J., Branthomme, A. (2001). Characterization of landscape patterns of deforestation in tropical rain forests. Int J Remote Sens 22:1753-1765.

39. Kaptan S. Durkaya A. (2019) Analysing Temporal and Spatial Changes in Land Cover: the Case of Drahna Forest Subdistrict Directorate",Kastamonu University Journal of Forestry Faculty, vol. 19, no. 1, pp. 47-56.

40. Kaptan, S. (2021) Investigation of temporal changes in land cover and in categories of forest development age and crown closure: The case of Karabiga Forest Planning Unit. Turk J For 22: 97-104.

41. Karanth, K.K., Curran, L.M., Reuning-Scherer, J.D. (2006). Village size and forest disturbance in Bhadra Wildlife Sanctuary, Western Ghats, India. Biol Conserv 128: 147-157.

42. Keles, S., Sivrikaya, F., Cakir, G., Baskent. E.Z., Kose, S. (2008). Spatial and temporal changes in forest cover in Turkey's Artvin Forest, 1972-2002. Pol J Environ Stud 17:491-501 
43. Keles, S., Durusoy, I., Cakir, G. (2016). Analysis of the changes in forest ecosystem functions, structure and composition in the Black Sea region of Turkey. J For Res 28: 329-342

44. Kilic, S., Evrendilek, F., Berberoglu, S., Demirkesen, A.C. (2004). Environmental monitoring of land-use and land-cover changes in Amik Plain, Turkey. Environ Monit Assess 114:157-168

45. Kucuker D.M., Kadiogullari, A.I., Gunlu, A., Baskent, E.Z. (2008). Analyzing of spatial and temporal changes of forest resources with geographic information system and remote sensing techniques: Case study in Akdamla. 5th International Conference on Geographic Information Systems (ISGIS-2008), 1-3 July 2008; Istanbul, Turkey. pp.155-162

46. Kucuker, D.M., Baskent, E.Z. (2017). Mediterranean pine nuts from forests and plantations. Options Méditerranéennes, Series A: Mediterranean Seminars, No. 122, Carrasquinho I, Correi A. C., Mutke S. Editor, Ciheam, Zaragoza, pp.7-12, 2017

47. Kupfer, J.A. (2006). National assessments of forest fragmentation in the US. Glob Environ Change 16:7382.

48. Laurance, W.F. (1999). Reflections on the tropical deforestation crisis. Biol Conserv 91:109-117.

49. Loehle, C., Li, B.L. (1996). Habitat destruction and the extinction debt revisited. Ecol Appl 6:784-789

50. Lomolino, M.V., Perault, D.R. (2000). Assembly and disassembly of mammal communities in a fragmented temperate rainforest. Ecology 81:1517-1532

51. Luque, S.S. (2000). The challenge to manage the biological integrity of nature reserves: A landscape ecology perspective. Int J Remote Sens, 21: 2613-2643

52. Mander, U., Mikk, M., Kulvik, M. (1999). Ecological and low intensity agriculture as contributors to landscape and biological diversity. Landsc Urban Plan 46: 169-177.

53. Mather, A.S., Needle, C.L., Fairbairn, J. (1998). Environmental Kuznets curves and forest trends, Geography 84: 55-65.

54. Nagashima, K., Sands, R., Whyte, A.G.D., Bilek, E.M., Nakagoshi, N. (2002). Regional landscape change as a consequence of plantation forestry expansion: an example in the Nelson region, New Zealand. For Ecol Manag 163:245-261

55. Naveh, Z., Lieberman, A.S. (1994). Landscape Ecology: Theory and Application. Springer Verlag: New York, NY.

56. Noss, R.F. (2001). Forest fragmentation in the southern rocky mountains. Landscape Ecology 16: 371-372.

57. Olsen, L.M., Dale, V.H., Foster, T. (2007). Landscape patterns as indicators of ecological change at Fort Benning, Georgia, USA. Lands Urban Plan 79: 137-149.

58. Onal, M. (2012). Medical and aromatic plants of Olur, Oltu and Senkaya. Master Thesis. Artvin Coruh University, Graduate Institute of Natural and Applied Sciences.

59. Puyravaud, J.P. (2003). Standardizing the calculation of the annual rate of deforestation. For Ecol Manag 177: 593-596.

60. Renjifo, L.M. (1999). Composition changes in a Subandean Avifauna after long-term forest fragmentation. Conserv Biol 13:1124-1139.

61. Sader, S.A., Hayes, D.J., Hepinstall, J.A., Coan, M., Soza, C. (2001). Forest change monitoring of a remote biosphere reserve. Int J Remote Sens 22:1937-1950

62. Shalaby, A., Tateishi, R. (2007). Remote sensing and GIS for mapping and monitoring land cover and landuse changes in the Northwestern coastal zone of Egypt. Appl Geogr 27: 28-41.

63. Shalaby, A., Aboel Ghar, M., Tateishi, R. (2004). Desertification impact assessment in Egypt using low resolution satellite data and GIS. Int J Environ Stud 61: 375-383.

64. Sivrikaya, F., Cakir, G., Kadiogullari, A.I., Keles, S., Baskent, E.Z., Terzioglu, S. (2007). Evaluating land use/land cover changes and fragmentation in the Camili forest planning unit of northeastern Turkey from 1972 to 2005. Land Degrad Dev 18:383-396

65. Sivrikaya, F., Cakir, G., Akay, A.E. (2011). Factors of land use and cover change: a case study from Turkey. Sci Res Essays 6:3684-3696

66. Spies, T.A., Ripple, W.J., Bradshaw, G.A. (1994). Dynamics and pattern of a managed coniferous forest landscape in Oregon. Ecol Appl 4: 555-568.

67. Steininger, M.K., Tucker, C.J., Ersts, P., Killeen, T.J., Villegas, Z., Hecht, S.B. (2001). Clearance and fragmentation of tropical deciduous forest in the Tierras Bajas, Santa Cruz, Bolivia. Conserv Biol 15: 856866.

68. TSMS (2016). Meteorology bulletin. Turkish State Meteorological Service, Ankara

69. TUIK (2020a). Turkish Statistical Institute, The Results of Address Based Population Registration System, Ankara

70. TUIK (2020b). Turkish Statistical Institute, Gross Domestic Product by Provinces, Ankara

71. Turner, M.G. (1989). Landscape ecology: The effect of pattern on process. Annu Rev Ecol Evol Syst 20: 171-197. 
72. Turner, M.G., Gardner, R.H. (1991). Quantitative Methods in Landscape Ecology. Springer-Verlag: New York, NY.

73. Turner, S.J., O’Neill, R.V., Conley, W., Conley, M.R., Humphries, H.C. (1991). Pattern and scale: Statistics for landscape ecology; p17-49. In Turner MG, Gardner RH (eds), Quantitative Methods in Landscape Ecology. Springer Verlag: New York, NY.

74. Turner, D.P., Koerper, G.J., Harmon, M.E., Lee, J.J. (1995). A carbon budget for forests of the conterminous United States. Ecol Appl 5: 421-436.

75. Turner, I.M., Corlett, R.T. (1996). The conversion value of small, isolated fragments of lowland tropical rain forest. Trends Ecol Evol 11: 330-333.

76. Turner, M.G., Gardner, R.H., O’Neill, R.V. (2001). Landscape ecology in theory and practice: pattern and process. Springer, New York

77. Xie, H., He, Y., Xie, X. (2016). Exploring the factors influencing ecological land change for China's BeijingTianjin-Hebei Region using big data. J Clean Prod, 142:677-687.

78. Wakeel, A., Rao, K.S., Maikhuri, R.K., Saxena, K.G. (2005). Forest management and land use/cover changes in a typical micro watershed in the mid-elevation zone of Central Himalaya, India. For Ecol Manag 213: 229-242

79. Wang, Z., Zhang, B., Zhang, S., Li, X., Liu, D., Song, K. et al (2006). Changes of land use and of ecosystem servie values in Sanjiang Plain, North China. Environ Monit Assess 112: 69-91

80. Watson, J.E.M., Freudenberger, D., Paull, D. (2001). An assessment of the focal-species approach for conserving birds in variegated landscapes in southeastern Australia. Conserv Biol 15: 1364-1373

81. Watson, J.E.M., Whittaker, R.J., Dawson, T.P. (2004). Habitat structure and proximity to forest edge affect the abundance and distribution of forest-dependent birds in tropical coastal forest of southern Madagascar. Biol Conserv 120:311-327

82. Wear, D.N., Turner, M.G., Flamm, R.O. (1996). Ecosystem management in a multi-ownership setting: exploring landscape dynamics in a Southern Appalachian watershed. Ecol Appl 6: 1173-1188.

83. Wu, Y., Zhang, X., Shen, L. (2011). The impact of urbanization policy on land use change: A scenario analysis. Cities 28: 147-159.

84. Zengin, H., Özdemir, H.Y., Degermenci, A.S. (2018). Determination of temporal changes in land uses in Hasanlar Dam basin. Forestist 68(1): 53-60

85. Zhao, B., Nakagoshi, N., Chen, J.K., Kong, L.Y. (2003). The impact of urban planning on land use and land cover in Pudong of Shanghai, China. J Environ Sci 15: 205-214. 